\title{
The dentition of the enigmatic pycnodont fish, Athrodon wittei (Fricke, 1876) (Neopterygii, Pycnodontiformes; Late Jurassic; NW Germany)
}

\author{
Jürgen Kriwet \\ Museum für Naturkunde der Humboldt-Universität zu Berlin, Invalidenstraße 43, 10115 Berlin, Germany. \\ E-mail: juergen.kriwet@museum.hu-berlin.de
}

\begin{abstract}
Received 1 December 2007

Accepted 26 January 2008

Published 1 August 2008

\section{Key Words}

Actinopterygii

Kimmeridgian

Taxonomy

Tooth arrangement

Dental evolution

Most pycnodontiform fishes are represented by their distinctive dentition alone, whereas articulated skeletons are very rare and the systematic position of most taxa based upon isolated teeth and the association of upper and lower dentitions to a specific taxon is still somewhat ambiguous in most cases. The vomerine dentition of the Late Jurassic pycnodontiform Athrodon wittei (Fricke, 1876), which is described here for the first time, is characterised by a high number of lateral tooth rows and the distinct morphology of the teeth. The dentition of Athrodon differs from most other pycnodont dentitions in the peculiar arrangement of the teeth into irregular rows and not well-differentiated principal row. The absence of regular tooth rows is not considered plesiomorphic here but most probably was achieved independently in different pycnodont lineages. The high number of lateral tooth rows ( $>$ four) is considered to be autapomorphic for Athrodon. The pycnodont fish Nonaphalagodus from the Albian of Texas, which also is known by isolated dentitions only, resembles Athrodon in the high number of vomerine tooth rows but differs in that this taxon displays the more derived feature of the teeth being arranged more regularly and individualized rows.
\end{abstract}

\section{Introduction}

The Pycnodontiformes is a monophyletic group of predominantly Mesozoic fishes with mostly deep and laterally compressed bodies (Nursall 1996, 1999; Kriwet 2001a; Poyato-Ariza \& Wenz 2002). They are highly specialised with regard to their prey, which is expressed in their durophageous dentition with rounded teeth arranged in more or less defined rows forming dental plates on the unpaired vomer in the upper and paired prearticulars in the lower jaws. The premaxillae and dentaries generally bear a single row of few grasping teeth, which are incisiform in more derived forms (Kriwet 2001b, 2003, 2005). Pycnodonts are considered to represent the sister group of teleosts (e.g., Arratia 1999: fig. 19; Kriwet 2001a). Some 700 nominal species belonging to several dozens of genera have been described to date. About ten genera are based entirely on isolated dentitions and only 78 species are known from skeletal remains. The evolutionary history of pycnodontiforms encompasses a period of approximately 175 million years (Delsate \& Kriwet 2004; Kriwet \& Schmitz 2005). They first appear in the Late Triassic (Norian) on the northern margins of Tethys (Tintori 1981) and persist into the Palaeogene (Eocene) (e.g., Longbottom 1984). During the Jurassic they rapidly diversified and pycnodont remains are common in marine and brackish sediments of Late Jurassic and Cretaceous age (Kriwet 2001c). They had a nearly world-wide distribution in the Mesozoic and Palaeogene and are considered major components of marine fossil fish assemblages. The distribution and ecology of pycnodont fishes has been described in general terms only to date by Schaeffer (1970), Nursall (1996a), Poyato-Ariza et al. (1999), and Kriwet $(2001 b, 2001 \mathrm{c})$. Most pycnodonts are small to medium sized fishes with a standard body length of some $25 \mathrm{~cm}$ or less. Only few large forms with a standard body length of more than $50 \mathrm{~cm}$ are known. Gyrodus circularis is the largest known pycnodont with a standard body length up to $200 \mathrm{~cm}$ (Kriwet \& Schmitz 2005). 
The main objective of this paper is to (1) describe the upper (vomerine) dentition of the enigmatic Late Jurassic pycnodont fish Athrodon wittei for the first time and (2) provide revised and extended diagnoses for the genus Athrodon and the species A. wittei.

\section{Material and locality}

The single specimen (MB f. 7135) that forms the focus of this paper and which represents the dentigerous upper jaw (vomer) of the pycnodontiform fish Athrodon wittei (Fricke, 1876) comes from the locality of Holzen near Hanover in northwestern Germany (Fig. 1) and was recovered from the so-called 'Pteroceras' layers (Aporrhais layers), which are Kimmeridgian (Late Jurassic) in age.

Abbreviations. BMNH, The Natural History Museum London; GZG, Geoscience Centre of the University of Göttingen, Museum, Collections \& Geopark; MB, Museum für Naturkunde der Humboldt-Universität zu Berlin.

\section{Systematic Palaeontology}

Order Pycnodontiformes Berg, 1937

Family incertae sedis

\section{Athrodon Sauvage, 1880}

Diagnosis (emended). Pycnodontiform fish only known from isolated dentitions and characterized by a combination of predominantly plesiomorphic and supposed autapomorphic feature (indicated by an asterisk $\left(^{*}\right)$. The prearticulars are massive and rather stout with a deep symphyseal facet. Prearticulars with oval to subcircular teeth; irregularly arranged and widely spaced $\left(^{*}\right)$. Principal series not well-differentiated $\left(^{*}\right)$. Up to two medial and several irregular lateral tooth rows. Teeth feebly mammilated and ornamented with striae along the crown borders when unworn. Vomer rather stout and massive, with the oral surface being strongly convex from side to side. One principal but not well-differentiated and more than four lateral tooth rows with rather irregularly arranged teeth $\left(^{*}\right)$. Main teeth are the largest, circular in outline with shallow, mammilated apical pits bordered by crimped margins and striae along the margins of the tooth crowns when unworn.

Type species. Athrodon douvillei Sauvage, 1880 from the Kimmeridgian (Late Jurassic) of Boulogne, northern France.

Jurassic taxa assigned to Athrodon. Athrodon boloniensis Sauvage, 1880; Athrodon douvillei Sauvage, 1880; Athrodon wittei (Fricke, 1876).

Cretaceous taxa included in Athrodon. Athrodon crassus Woodward, 1893; Athrodon intermedius Woodward, 1893; Athrodon jessoni Woodward, 1895a; Athrodon profusidens (Cornuel 1886); Athrodon sp. Woodward, 1893; Athrodon sp. Priem, 1911; Athrodon tenuis Woodward, 1893.

\section{Athrodon wittei (Fricke 1876)}

1876 Mesodon wittei Fricke: 364, pl. 19, fig. 15

1880 Mesodon wittei. - Sauvage: 531.

1893 Athrodon wittei. - Woodward: 2.

1895b Athrodon wittei. - Woodward: 217.

2005 Athrodon wittei. - Kriwet: fig. 43.

Diagnosis (emended). Prearticular teeth widely spaced with principal teeth being the largest (about 2.5 times larger than the adjacent ones) and circular in outline. Medial teeth small, oval in outline and ar- ranged in two very irregular tooth rows. Teeth of the lateral tooth rows as large as medial teeth and irregularly arranged in six tooth rows on each side of the principal row. Vomer with one principal and at least six lateral tooth rows. Main teeth are the largest, subcircular to oval in the posterior and circular to slightly rectangular in the anterior portion of the vomer. Teeth of the first lateral row are inserted completely into spaces between the main teeth posteriorly and anteriorly. Occlusal surfaces of the teeth almost vertically arranged from the third tooth row on. Teeth of the third lateral tooth row are the largest of all lateral teeth being oval in outline with their long axes arranged vertically to the long axis of the vomer. Teeth of the fourth lateral row are the smallest. Some very small circular teeth lateral to the sixth tooth row.

Holotype. GZG.V.21737, isolated right prearticular dentition. The specimen is stored under publication number 762 .

Locus typicus. Tönjesberg, near Hanover, northwestern Germany (Fig. 1).

Stratum typicum. "Pteroceras-Schichten", lower Kimmeridgian, Late Jurassic.

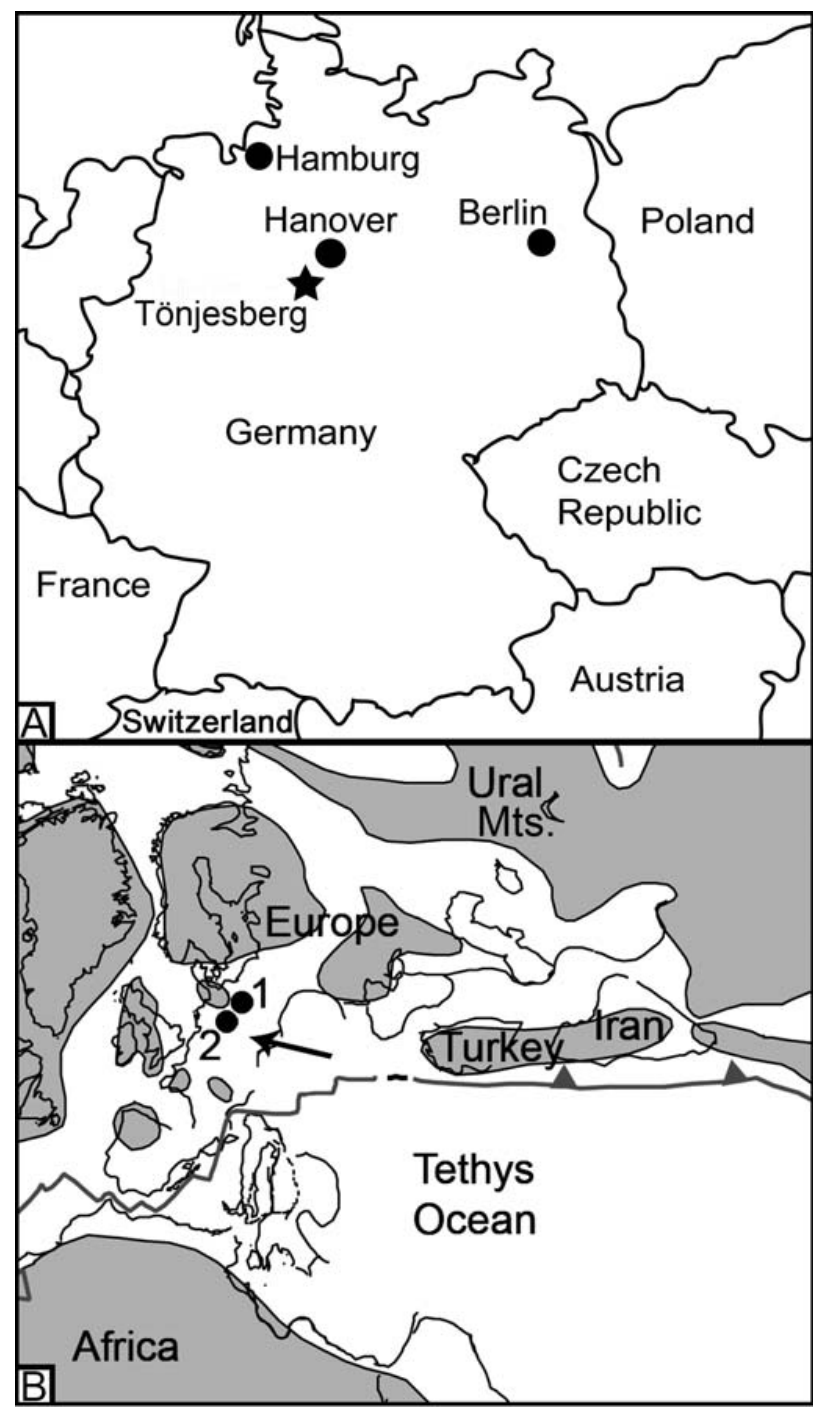

Figure 1. A. Sketch map of Germany showing the locality of Tönjesberg near Hanover. B. Palaeogeographic positions of Berlin (1) and Tönjesberg (2) in the Late Jurassic. The arrow indicates the position of the Late Jurassic lithographic limestones of the Solnhofen area. Base map modified from Scotese (1999). 
Geographic and stratigraphic distribution. Species only known from the type locality and horizon.

Remarks. The holotype is a fragmentary prearticular (Fig. 2); only the posterior portion with parts of the coronoid process is preserved. It displays an irregular medial, a principal, and five to six irregular lateral tooth rows. The teeth of the medial tooth row are subcircular in outline and exhibit a shallow apical furrow with crimped walls. The principal teeth are the largest. They are circular in outline and are about twice as large as the teeth of the medial and the first lateral tooth rows. A single tooth bears some short striae at its anterior crown margin, an apical furrow is not preserved. The lateral teeth are irregularly arranged and the differentiation of rows is obscured.

Description. The single, isolated vomerine dentition that forms the focus of this paper from Tönjesberg, MB f. 7135 (Fig. 3), differs from most pycnodont dentitions in its tooth arrangement and morphology. It is rather stout and massive. In occlusal view, the dentigerous part is wedge-like. The posterior limb of the vomer bone, which forms the contact with the supporting edentulous parasphenoid in the living animal, lacks teeth and tapers rapidly caudally. The oral surface of the dentigerous portion is strongly convex from side to side. This indicates that the prearticulars, which form the functional lower jaw, form a rather deep and round mortar, into which the vomer fits like a pestle (compare Kriwet 2003: fig. 6).

The vomer bears a principal row and at least six more or less longitudinal tooth rows on each side adjacent to the main row. The main row consists of about seven teeth, which are the largest teeth of the dentition. Six teeth are broken off; only the bases are preserved. They are subcircular to oval in the posterior and circular to slightly rectangular in the anterior portion in oc-

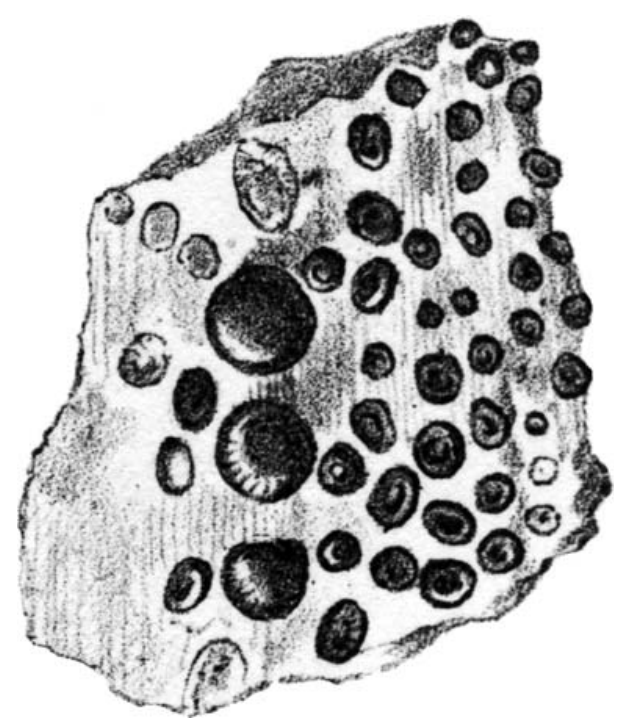

Figure 2. The holotype, an isolated, fragmentary prearticular of Athrodon wittei (Fricke, 1876) from the Kimmeridgian of Tönjesberg near Hanover (after Fricke 1876: pl. 2, fig. 15).

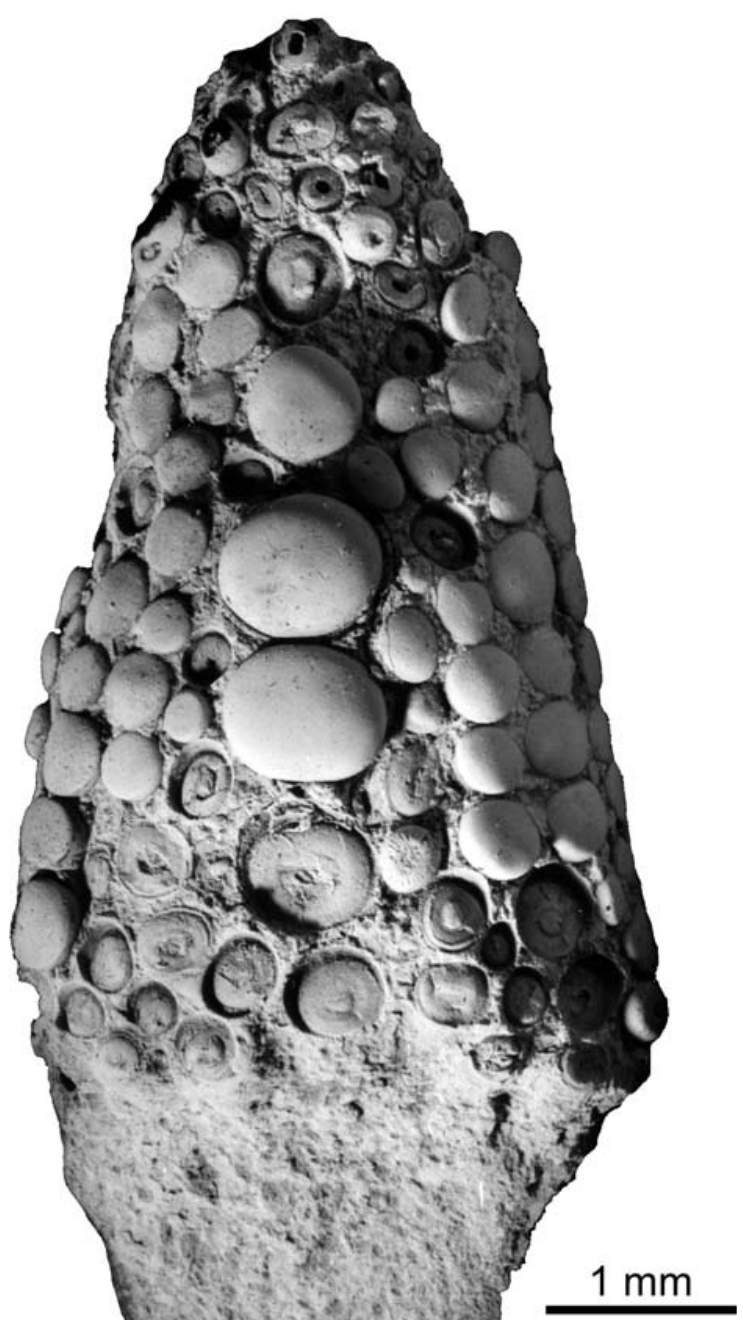

Figure 3. Isolated vomerine (upper) dentition of Athrodon wittei (Fricke, 1876) (MB f. 7135) from the Kimmeridgian of Tönjesberg near Hanover (NW) Germany.

clusal view. The largest main teeth occur in the middle portion of the dentition. The occlusal surface of all main teeth is completely smooth most probably due to their elevation compared to lateral teeth and thus being more exposed to grinding effects.

The lateral teeth are closely arranged in six irregular tooth rows on each side of the principal tooth row. The teeth of the first lateral row are inserted completely into spaces between the main teeth in the posterior and anterior portion. The teeth of the first two lateral rows are small and circular in outline. The occlusal surfaces of the teeth are vertically oriented from the third tooth row on. The teeth of the third lateral tooth row are the largest of the lateral teeth. They are oval in outline with their long axes arranged perpendicular to the long axis of the vomer. The teeth of the fourth lateral tooth row are the smallest. They are circular in outline as are the teeth of the adjacent lateral tooth rows. There are some very small circular teeth lateral to the sixth tooth row. Most lateral teeth are deeply worn and have lost their ornamentation. Only few, small teeth exhibit a shallow, sometimes mammilated apical pit with crimped mar- 
gins. There are also striae preserved along the margins of the tooth crown.

Discussion. Late Jurassic fishes from different outcrops near Hanover were described in a monograph by Fricke (1876). He reported numerous hybodont sharks, three species of Lepidotes, and a rather diverse pycnodont fish fauna. Unfortunately, almost all of these records are based solely on isolated dentitions or teeth. The only skeletal pycnodont remains from the Late Jurassic of northern Germany consisting of a partially preserved skull and associated postcranial elements was attributed to "Mesodon" granulatus by Fricke (1876). Subsequently, Fricke (1876) attributed almost all isolated pycnodont dentitions to the taxon Mesodon. However, the taxon Mesodon, as it is now generally accepted, represents an unnatural grouping of several unrelated taxa (e.g., Kriwet 2001a; Poyato-Ariza \& Wenz 2002, 2004). Woodward (1918) already recognized this and created the genus Eomesodon in an attempt to clarify its taxonomy. Poyato-Ariza \& Wenz $(2002,2004)$ identified at least two genera based on specimens, which have been attributed to Eomesodon and Macromesodon respectively (see discussion in Poyato-Ariza \& Wenz 2004). All taxa previously referred to Eomesodon and Macromesodon are characterised by five longitudinal tooth rows on the vomer. The prearticular dentitions attributed to the different species of Mesodon by Fricke (1876) (M. granulatus, M.rugulosus, M.wittei, M. laevior, M. pusillus, M. minutus, M. hugii) vary significantly in the number and arrangement of teeth and tooth rows. Some of these species can be referred to Eomesodon or Apomesodon (e.g., M. granulatus, M.rugulosus), while the generic attribution of most others remains unclear at the moment. Isolated vomerine dentitions of "Mesodon" with five longitudinal tooth rows might belong to Macromesodon rather than Turbomesodon.

Sauvage (1880) introduced the pycnodont genus Athrodon for isolated prearticular dentitions from the Late Jurassic of northern France. The characteristic feature of this genus, which is only known by isolated dentitions, is the high dental number comprising small and rounded teeth (Fig. 4). These teeth are of similar size to each other with an ornamentation very similar to that found in Gyrodus spp. (see for instance Thies (1985) and Kriwet (1999) for a description of Gyrodus dental features). Woodward (1895b) characterised the prearticular dentition of Athrodon as being similar to that of Mesodon but stouter and with a more pronounced symphysis. The teeth form more than five tooth rows and are more irregularly arranged than in Macromesodon s. str. with an inconspicuous main row. Vomerine dentitions of Athrodon, conversely, are very incompletely known and most species are known by their prearticulars only. The vomerine dentition of Athrodon wittei also has been unknown until now.

Several isolated dentitions from Cretaceous deposits have been included within Athrodon. For instance, Woodward (1893) described an isolated vomerine denti- tion from the Cambridge Greensand of southern England, which he identified as belonging to Athrodon without any specific assignment. The specimen bears a principal, rather inconspicuous tooth row of circular teeth which are arranged longitudinally and which are only slightly larger than the adjacent teeth. The specimen (BMNH P.7186) exhibits at least four tooth rows lateral to the principal row with circular teeth (Woodward 1893: pl. 16, fig. 4; Woodward 1895a: pl. 17, fig. 2; pers. observ.). The teeth exhibit an apical pit, which may bear a central papilla. The margins are crimped when not worn down. The oral surface of the vomer is strongly convex. Another fragmentary vomerine dentition, BMNH P.11276, from the Late Jurassic (Tithonian) of Brunswick (Germany) bears rounded teeth of similar size, which are arranged in about 10 very irregular tooth rows. The number of lateral tooth rows (more than five) in combination with teeth of similar size and morphology in all tooth rows is quite atypical for pycnodonts. The vomerine teeth are arranged in five more or less longitudinal rows in most pycnodonts (e.g., Apomesodon, Coelodus, Gyrodus, Iemanja, Macromesodon, Mesturus, Nursallia, Oeclodus, Proscinetes). The vomerine dentition of the Late Jurassic and Early Cretaceous Turbomesodon, conversely, bears only three longitudinal tooth rows (Poyato-Ariza $\&$ Wenz 2004). Although the conjunction of isolated vomerine and prearticular dentitions is rather doubtful in most cases, it seems reasonable to combine vomerine and prearticular dentitions with similar numbers of tooth rows and tooth morphology and ornamentation when they occur together in the same locality.

The only other pycnodont with more than seven vomerine tooth rows is Nonaphalagodus trinitiensis from the Albian of Texas (Thurmond 1974). This taxon, however, differs readily from Athrodon in the closer and more regular arrangement of teeth, the more individualised principal tooth row, and the absence of the characteristic ornamentation.

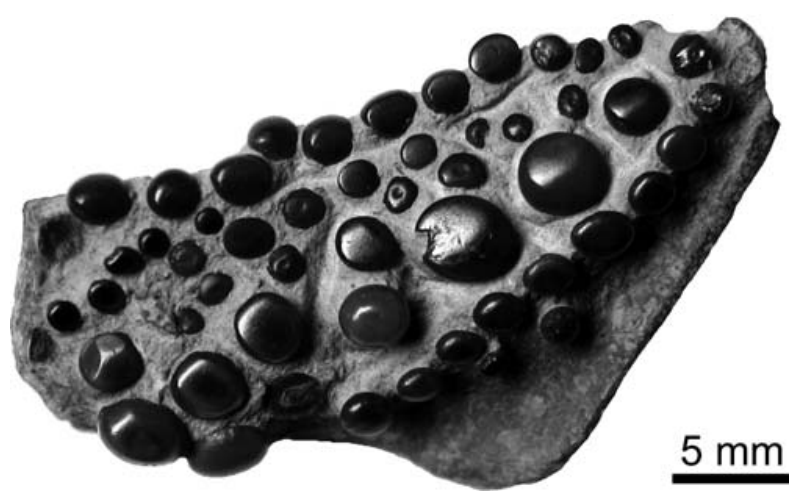

Figure 4. Isolated prearticular dentition of Athrodon sp. (MB f. 1337) from the Argile de Dives inférieur, Kelloways Rock, Callovian of Les vaches noires near Dives sur-mer (Dépt. du Calvados), Normandie, France displaying the characteristic tooth form and tooth arrangements of the lower jaw. 


\section{Geographic and stratigraphic occurrences of Athrodon}

So far, eight species of Athrodon ranging from the Late Jurassic to the Late Cretaceous have been described, but they are only known from their prearticular dentitions. The known distribution of all these taxa is restricted to marine deposits in Central Europe. Rare discoveries of isolated dentitions indicate that this taxon also occurs in the Middle Jurassic (e.g., Fig. 4). In the Kimmeridgian, Athrodon shows a very restricted distribution and has been reported from Tönjesberg in northwestern Germany (A. wittei Fricke, 1876), Boulogne in France (A. boloniensis Sauvage, 1867; A. douvillei Sauvage, 1880) and Fumel in France (A.boloniensis; Sauvage 1902). Hauterivian pycnodonts are well-known from the Paris Basin and Cornuel $(1883,1886)$ indicated the presence of Athrodon profusidens amongst others. Since the papers of Woodward (e.g., 1888, 1893, 1895a, 1895b, 1909), the Chalk succession (Chalk group) of southern England is known for its abundant fish fossils of Late Cretaceous age. A diverse fish fauna consisting of isolated remains was recovered in the $19^{\text {th }}$ century from the base of the Lower Chalk, which is marked by the Cambridge Greensand (lower Cenomanian) in the north-eastern part of southern England and includes Athrodon crassus and A.jessoni (Woodward 1893). Woodward (1893) also indicated the presence of Athrodon in the Santonian of Lonzée in Belgium, which, however, more likely belongs to Anomoeodus. In addition, Priem (1898) described dental remains of Athrodon sp. from the lower Senonian (Turonian?) of Saint-Paterne in northwestern France. The presence of Athrodon in the Cretaceous, however, is very questionable and each of the reported remains might represent different taxa.

\section{Conclusions}

The vomerine dentition described in this study is characterised by its high number of lateral tooth rows and morphology of the teeth. It is very similar to the English specimen assigned to Athrodon. Therefore, the specimen from Tönjesberg near Hanover is placed within Athrodon. The fish fauna from northwestern Germany described by Fricke (1876) includes many species of Mesodon. "Mesodon" wittei, which was based on a single and fragmentary specimen was compared with Athrodon douvillei and Athrodon boloniensis by Sauvage (1880) and was ascribed to Athrodon by Woodward (1893). The above described vomer, which occurs together with the prearticular of A. wittei in the same sediments and locality, is combined with the latter because both share important characters such as tooth arrangement, peculiarities in tooth row morphology, and tooth form and ornamentation.
The attribution of the vomerine dentition described above to $A$. wittei, in addition to the morphology of the two other vomerine dentitions housed in The Natural History Museum, London, allows revision the generic and species diagnoses of $A$. wittei. Most notably, the dentition of Athrodon differs from most other pycnodont dentitions in the peculiar arrangement of the teeth into rows. In most pycnodonts, the teeth on the vomer and prearticulars are generally arranged in well-defined tooth rows. This is also the case in plesiomorphic taxa (e.g., Mesturus, Gyrodus, Brembodus, Gibbodus and others; compare Kriwet 2000, 2005). Iemanja palma from the Early Cretaceous of Brazil is the only other pycnodontiform in which the teeth are arranged in a very irregular fashion forming indistinct tooth rows. Consequently, the absence of regular tooth rows is not considered plesiomorphic but probably was apomorphic and achieved independently in different pycnodont lineages. The high number of lateral tooth rows ( $>$ four) is considered to be autapomorphic for Athrodon. Nonaphalagodus from the Albian of Texas resembles Athrodon in the high number of vomerine tooth rows but differs in that this taxon displays the more derived feature of the teeth being arranged more regularly and individualized rows.

The combination of vomerine and prearticular tooth arrangements and the number of tooth rows is considered to show a taxonomic signal and is therefore indicative for pycnodonts at least on generic level (Kriwet 2001, 2003) in spite of the fact that Poyato-Ariza (2003) strongly argued against using dental characters for assessing the systematic position of taxa within Pycnodontiformes. Consequently, the genus Athrodon, which is only known by isolated dentitions is left as Family incertae sedis here.

\section{Acknowledgements}

I am indebted to G. Arratia and H.-P. Schultze (Lawrence, Kansas, U.S.A.) for their continuous help, suggestions, and discussions of pycnodontiform anatomy and phylogenies in the last few years. The manuscript has benefited greatly from reviews and comments provided by R. Böttcher (Stuttgart, Germany), C. Duffin (Surrey, UK), and D. Korn (Berlin, Germany). P. Forey, M. Richter, and A. Longbottom (The Natural History Museum, London, UK) are acknowledged for giving permission to study specimens under their care. I thank J. R. Nursall (Whaletown, Canada), F. J. Poyato-Ariza (Madrid, Spain), D. Thies (Hanover, Germany), A. Tintori (Mailand, Italy), and S. Wenz (Paris, France) for discussions on pycnodont characters and taxonomy. M. Reich (Göttingen, Germany) provided information on the holotype of Athrodon wittei. S. Klug (Berlin, Germany) is acknowledged for formatting the manuscript.

\section{References}

Arratia, G. 1999. The monophyly of Teleostei and stem-group teleosts: Consensus and disagreements. In Arratia, G. \& Schultze, H.-P. (eds). Mesozoic Fishes 2 - Systematics and the fossil record. Verlag Dr. Friedrich Pfeil, München: pp. 265-334.

Berg, L. S. 1937. A classification of fish-like vertebrates. - Bulletin de l'Académie des Sciences de l'URSS 4: 1277-1280. 
Cornuel, M. J. 1883. Nouvelle note sur des pycnodontes portlandiens et néocomiens de l'Est du bassin de Paris, et sur des dents binaires de plusieurs d'entre eux. - Bulletin de la Société géologique de France 11. Sér. 3: 18-27.

Cornuel, M. J. 1886. Liste des fossiles du terrain crétacé inférieur de la Haute-Marne. - Bulletin de la Société géologique de France 14. Sér. 3: 312-323.

Delsate, D. \& Kriwet, J. 2004. Late Triassic pycnodont fish remains (Neopterygii, Pycnodontiformes) from the Germanic Basin. Eclogae geologicae Helvetiae 97: 183-191.

Fricke, K. 1876. Die fossilen Fische aus den oberen Juraschichten von Hannover. - Palaeontographica 22: 347-398.

Kriwet, J. 1999. Pycnodont fishes (Neopterygii, †Pycnodontiformes) from the upper Barremian (Lower Cretaceous) of Uña (Cuenca Province, E-Spain) and branchial teeth in pycnodontid fishes. In Arratia, G. \& Schultze, H.-P. (eds). Mesozoic Fishes 2 - Systematics and the fossil record. Verlag Dr. Friedrich Pfeil, München: pp. $215-238$.

Kriwet, J. 2000. Revision of Mesturus cordillera Martill et al., 1998 (Actinopterygii, Pycnodontiformes) from the Oxfordian (Upper Jurassic) of northern Chile. - Journal of Vertebrate Paleontology 20: 450-455.

Kriwet, J. 2001a. A comprehensive study of pycnodont fishes (Neopterygii, Pycnodontiformes): Morphology, Taxonomy, Functional Morphology, Phylogeny, and Palaeobiogeography. PhD-thesis, Humboldt-Universität zu Berlin, Berlin: 580 pp.

Kriwet, J. 2001b. Feeding mechanisms and ecology of pycnodont fishes (Neopterygii, †Pycnodontiformes). - Mitteilungen aus dem Museum für Naturkunde zu Berlin, Geowissenschaftliche Reihe 4: $139-165$.

Kriwet, J. 2001c. Palaeobiogeography of pycnodontiform fishes (Actinopterygii, Neopterygii). - Seminario de Paleontología de Zaragoza 5.1: $121-130$.

Kriwet, J. 2003. Dental Morphology of the pycnodont fish $\dagger$ Stemmatodus rhombus (Agassiz 1844) (Neopterygii, † Pycnodontiformes) from the Early Cretaceous with comments on its systematic position. Transactions of the Royal Society of Edinburgh 94: 145-155.

Kriwet, J. 2005. A comprehensive study of the skull and dentition of pycnodont fishes (Neopterygii, Pycnodontiformes. - Zitteliana 45: $135-188$

Kriwet, J. \& Schmitz, L. 2005. New insight into the distribution and palaeobiology of the pycnodont fish Gyrodus. - Acta Palaeontologica Polonica 50: 49-56.

Longbottom, A. E. 1984. New Tertiary pycnodonts from the Tilemsi valley, Republic of Mali. - Bulletin of the British Museum (Natural History), Geology 38: 1-26.

Nursall, J. R. 1996a. Distribution and ecology of pycnodont fishes. In Arratia, G. \& Viohl, G. (eds). Mesozoic Fishes - Systematics and Paleoecology. Verlag Dr. Friedrich Pfeil, München: pp. 115124.

Nursall, J. R. 1996b. The phylogeny of pycnodont fishes. In Arratia, G. \& Viohl, G. (eds). Mesozoic Fishes - Systematics and Paleoecology. Verlag Dr. Friedrich Pfeil, München: pp. 125-152.

Nursall, J. R. 1999. The pycnodontiform bauplan: The morphology of a successful taxon. In Arratia, G. \& Schultze, H.-P. (eds). Mesozoic Fishes 2 - Systematics and Fossil Record. Verlag Dr. Friedrich Pfeil, München: pp. 189-214.
Poyato-Ariza, F. J. 2003. Dental characters and phylogeny of pycnodontiform fishes. - Journal of Vertebrate Paleontology 23: 937-940.

Poyato-Ariza, F. J., Fielitz, C. \& Wenz, S. 1999. Marine actinopterygian fauna from the Upper Cretaceous of Albaina (Lano Quarry, northern Spain). - Estudios del Museo de Ciencias naturales de Alava 14 (Núm. Esp. 1): 325-338.

Poyato-Ariza, F. J. \& Wenz, S. 2002. A new insight into pycnodontiform fishes. - Geodiversitas 24: 139-248.

Poyato-Ariza, F. J. \& Wenz, S. 2004. The new pycnodontid fish genus Turbomesodon, and a revision of Macromesodon based on new material from the Lower Cretaceous of Las Hoyas, Cuenca, Spain. In Arratia, G. \& Tintori, H.-P. (eds). Mesozoic Fishes 3 - Systematics, Paleoenvironments and Biodiversity. Verlag Dr. Friedrich Pfeil, München: pp. 341-378.

Priem, F. 1898. Sur des pycnodontes et des squales du Crétacé supérieur du Bassin de Paris (Turonien, Sénonien, Montien inférieur). Bulletin de la Société géologique de France, Sér. 3 26: 229-243.

Priem, F. 1911. Étude des poissons fossiles du Bassin Parisien (Supplément). - Annales de Paléontologie 6: 1-44.

Sauvage, H. É. 1867. Poissons fossiles des formations secondaires du Boulonnais. - Mémoires de la Société académique du Boulonnais 2: $53-152$.

Sauvage, H. É. 1880. Synopsis des poissons et des reptiles des terrains jurassiques de Boulogne-sur-Mer. - Bulletin de la Société géologique de France, Sér. 3 8: 524-547.

Sauvage, H. É. 1902. Recherches sur les Vertébrés du Kimméridgien supérieur de Fumel. - Mémoires de la Société géologique de France, Paléontologie 25: 5-32.

Schaeffer, B. 1970. Mesozoic fishes and climate. - Proceedings of the North American Paleontological Convention 1: 376-388.

Scotese, C. R. 1999. Paleogeographic Atlas. Paleomap Progress Report 90-0497, University at Arlington, Texas: 21 pp. +2 CDs.

Thies, D. 1985. Eine Gaumenbezahnung von Gyrodus aus dem fränkischen Malm Gamma. - Geologische Blätter NordostBayerns 34/35: 389-406.

Thurmond, J. T. 1974. Lower vertebrate faunas of the Trinity Division in North-Central Texas. - Geoscience and Man 3: 103-129.

Tintori, A. 1981. Two new pycnodonts (Pisces, Actinopterygii) from the Upper Triassic of Lombardy (N. Italy). - Rivista Italiana di Paleontologia 86: 795-824.

Woodward, A. S. 1888. A synopsis of the vertebrate fossils of the English Chalk. - Proceedings of the geological Association 10: $273-338$.

Woodward, A. S. 1893. Some Cretaceous pycnodont fishes. - Geological Magazine, dec. 3, 10 352: 433-451.

Woodward, A. S. 1895a. A synopsis of the remains of ganoid fishes from the Cambridge Greensand. - Geological Magazine, dec. 4, 2 371: 207-214.

Woodward, A. S. 1895b. Catalogue of the fossil fishes in the British Museum (Natural History). Part III, British Museum (Natural History), London: XIV + $544 \mathrm{pp}$

Woodward, A. S. 1909. The fossil fishes of the English Chalk. Part V. - Monographs of the Palaeontographical Society, British Museum (Natural History), London: pp. 153-184.

Woodward, A. S. 1918. The fossil fishes of the English Wealden and Purbeck Formations. Part 2. - Monographs of the Palaeontographical Society 70: 49-104. 